\title{
Archiv
}

für das Studium der neueren Sprachen und Literaturen

Herausgegeben von JENS HAUSTEIN CHRISTA JANSOHN BARBARA KUHN MANFRED LENTZEN DIETER MEHL

250. Band

165. Jahrgang

2. Halbjahresband 2013 


\section{The Correspondence between Charles Dickens and Bernhard Tauchnitz: General Observations and Newly Discovered Letters}

To my father Gunter Böbnke, the begetter of the following, on bis seventieth birthday

\section{By DietMar BöHNKE (Leipzig)}

Abstract:

The correspondence between Charles Dickens and Bernhard Tauchnitz (1816-1895), founder of the Tauchnitz Verlag in Leipzig, spans almost thirty years, between 1843 and 1870 - Dickens was one of the key authors in the Tauchnitz Edition, a series of books in English for Continental sale initiated in 1841. So far, only 29 of Dickens's letters to Tauchnitz were known (and printed in the authoritative Pilgrim Edition), and none of the manuscripts could be consulted. In 1991, Gunter Böhnke discovered 34 of the original letters in Leipzig, of which 14 are unknown and seven others only in short extracts. This article briefly sketches the background of the relationship between Dickens and Tauchnitz, and reprints for the first time these 21 letters as transcribed from photocopies of the originals. In the footnotes, the other 22 known letters to Tauchnitz are also listed. As a whole, they illustrate Dickens's interest in the publication of his works abroad (including payment for this, obviously), as well as his high regard for Tauchnitz. Among the personal information that can be glimpsed from the letters, the most interesting is probably Dickens's son Charley's two-year stay in Leipzig in 1853-4.

Keywords:

Charles Dickens, Bernhard Tauchnitz, letters, Tauchnitz Edition, Pilgrim Edition

\section{Introduction}

The bicentenary year of Charles Dickens's birth in 2012 coincides with the 175th anniversary of the Leipzig publishing firm of Bernhard Tauchnitz (founded 1 February 1837), which achieved almost universal recognition with its Collection of English (and American) Authors between 1841 and 1943, commonly known as Tauchnitz Edition. This English-language series of predominantly novels, but also poetry, plays and non-fiction by mostly contemporary authors, published by Tauchnitz for distribution on the Continent and later in the USA and all other non-British territories, ran to nearly 5,400 volumes by c. 700 authors, and can thus be seen as a representative survey and 
record of English and American literature in this period. ${ }^{1}$ In 1843, the founder of the firm Christian Bernhard Tauchnitz (1816-1895) personally approached several eminent British authors to ask their permission for publishing their works on the Continent, and offered to pay them for this. Legally, he was not required to do this, since no international copyright agreements existed at the time. Therefore, he has been seen as a pioneer in the development of copyright, and earned the respect, indeed the friendship, of many English-language writers over the next fifty years. ${ }^{2}$ It is not surprising, therefore, that his correspondence with many of these writers is voluminous, and constitutes an immensely interesting document and resource for historical, literary and cultural analysis. We have some record of this correspondence in the form of extracts from letters written to Tauchnitz (and later his son and successor, Christian Carl Bernhard von Tauchnitz) by eminent writers and statesmen, published in the various Festschriften of the firm, e.g. in 1887, 1912 and $1937 .{ }^{3}$

1 There is a small but growing body of literature on the Tauchnitz firm, to which I m indebted in the following: next to the original anniversary publications of the firm (cf. footnote 3 below) and Gunter Böhnke's articles (see fn 5), I would like to single out Christa Jansohn, "The Impact of Bernhard Tauchnitz's Book Series 'Collection of British and American Authors' on the Continent and Beyond", in: Angermion, 3 (2010), 161184; Thomas Keiderling, "Ein wesentlicher Beitrag zur weltweiten Verbreitung des englischen Buchs. Der Leipziger Verleger Bernhard Tauchnitz (1816-1895) und der Tauchnitz-Verlag", in: Anglosachsen: Leipzig und die englischsprachige Kultur, ed. Stefan Welz / Fabian Delleman (Frantfurt am Main: Peter Lang 2010) pp. 89-98; Simon Welz /l- Fabin "Fir Taun (1837-1900" in: The Book Collector, 15, 4 (Winter 1966), 423-436; Karl H. Pressler, "The Tauchnitz Edition: Beginning and End of a Famous Series", in: Publishing History, 6 (1979), 63-78; and of course the monumental "bibliographical history" by William B. Todd / Ann Bowden, Tauchnitz International Editions in English 1841-1955: A Bibliographical History (New Castle, Delaware and London: Oak Knoll Press and The British Library, 2003 [1988]), hereafter referred to as Todd / Bowden.

2 It is debatable whether Tauchnitz did this because he genuinely felt it was the 'rites' due or whether he wanted to secure a competitive advantage once copyright wites due, or whe her he wanted to secure a cons at the that such agreements were agreements were in place. mminent, and they did in fact come into existence between Britain and Prussia/Saxony he cleverly used, and in the process became one of the richest men in Saxony.

3 The titles are: Fünfzig Jabre der Verlagsbuchbandlung Bernbard Taucbnitz 1837 bis 1887 [by Christian Carl Bernhard Tauchnitz] (Leipzig: Bernhard Tauchnitz, 1887); Der Verlag Bernhard Tauchnitz 1837-1912. Mit einem Anbang enthaltend Auszüge aus den Briefen englischer und amerikanischer Autoren der Tauchnitz Edition [by Curt Otto] (Leipzig: Bernhard Tauchnitz, 1912); The Harvest: Being the Record of One Hundred Years of Publishing 1837-1937. Offered in Gratitude to the Friends of the Firm by

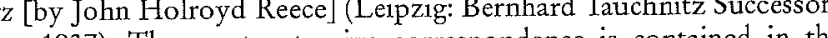
Brandstetter \& Co., 1937). The most extensive correspondence is contained in the second of these (referred to hereafter as Der Verlag), which is also the source for almost all the letters from Dickens to Tauchnitz that were hitherto known and contained in the
Among these writers, Charles Dickens is always singled out for his particular importance to and his close friendship with the publisher, and extracts from his letters usually take up the longest sections in these publications. Until now, the originals of these letters were presumed lost. ${ }^{4}$ However, in 1991 the father of the present author, Gunter Böhnke, ${ }^{5}$ discovered 34 of Dickens's letters to Tauchnitz and about 30 others by various Dickens family members, other publishers etc. in the archive of one of the state-owned publishing and printing firms that were about to be dismantled in the wake of German unification. ${ }^{6} \mathrm{He}$ photocopied and transcribed them and handed them back to the company, where they were subsequently lost - they have not reappeared so far, and are not contained in the few remains of the Tauchnitz archive at the Staatsarchiv Leipzig. Luckily, the photocopies have remained in the possession of our family. This article, then, gives a brief overview of the relationship and correspondence between Dickens and Tauchnitz, and reprints for the first time those letters hitherto unpublished or published only in severely truncated form.

definitive Pilgrim Edition of the Letters of Charles Dickens, ed. Madeline House, Graham Storey, Kathleen Tillotson et al.. 12 vols. (Oxford: Clarendon Press, 1965-2002) hereafter referred to as $\mathrm{PE}$ (with the volume in Roman numerals). It is a cause for regret that there are very few traces of the letters that Tauchnitz himself wrote.

${ }^{4}$ In the literature on Tauchnitz, the assumption is that most or all of the archive was destroyed in the bombing of Leipzig on 3 and 4 December 1943, when the firm of the then owner of the company, Oscar Brandstetter suffered major damage. Cf. NowellSmith op. cit, p. 428. "Unfortunately all the many hundreds of letters preserved by the firm, together with their stock of publications, stereotype plates and printing plant, were firm, together with their stock of publication,
destroyed in an air-raid on Leipzig in 1943."

destroyed in an air-raid on Leipzig in 1943."
5 Gunter Böhntse used to be foreign-language editor with the Leipzig publisher Edition Leipzig, worked as a literary translator and went on to become a well-known actor and comedian with one of the Leipzig Kabaretts (political-satirical theatres), the academixer. He published two separate articles on Bernhard Tauchnitz in 1990 (one of these in two parts), as a result of which he made the discovery with which we are concerned here: "Die Konkurrenz aus dem Feld geschlagen: Der Leipziger Verleger

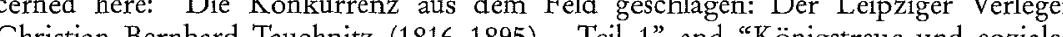
Christian Bes "Doziales Engagement: Der Leipziger Verleger Chnstan Bernhard Tauchnitz - Teil 2", in: Börsenblatt für den deutschen Buchbandel (Leipziger Ausgabe), No. 4+5 (1990), 66-68+90-92, "Angelsächsisches in Sachsen: Der Verlag von Christian Bernhard Tauchnitz", in: Leipziger Blätter, 17 (Herbst 1990), 57-59.

6 The reason why part of the archive was obviously still in the (former) GDR at this time was that the owners of Bernhard Tauchnitz Verlag after WW2, the descendants of Oscar Brandstetter, left the Russian occupation zone of Germany rather hurriedly in 1947, and obviously could not take what was left of the archives with them Those remains whe oublishing concerns of the GDR, such as Bibliographisches Institut Leipzig (cf. the various files in
the Staatsarchiv Leipzig). 


\section{Dickens and Tauchnitz}

Charles Dickens was one of the central authors in the Tauchnitz Edition from the very start: he provides volumes 2 and 3 of the series with his Pickwick Papers (still as "pirated editions"), and all of his works after 1843 were published simultaneously with their British release by Tauchnitz - in one or two cases even slightly earlier, making the Tauchnitz edition a genuine first edition of Dickens in book form. ${ }^{7}$ In addition to these works, there were many volumes (nearly 50) of material reprinted from Dickens's journal Housebold Words, taking the overall number of Dickens volumes in the series close to 100. It is not surprising, therefore, to find that all the anniversary publications of the Tauchnitz firm give pride of place to Dickens as their most prominent author. Dickens was among the first authors approached by Tauchnitz in 1843, and given his concern over pirated editions at the time and generally his ambition to maximize his profit from his writings, he responded eagerly and positively to the proposal: "In reply to your letter I beg to say that if you will favour me with any distinct proposition ... I shall be happy to give it immediate consideration." - this is the first record we have of Dickens's communication with Tauchnitz (9 October 1843, PE III, p. 579; not contained among our letters). Clearly, Tauchnitz did make a distinct proposition, and Dickens accepted it, so that in December that year A Christmas Carol could be advertised as an "edition sanctioned by the author" (similar formulations were now printed on all volumes of the Tauchnitz Edition). The usual remuneration by Tauchnitz for exclusive publication rights outside the British Empire seems to have been £30-50, which was quite generous for the time. However, our letters show that the sum for a single new book could be as high as $£ 150$ (letter of 22 February 1864, referring to Our Mutual Friend ${ }^{8}$, PE X, p. 360, see also fn 41 below), and that there were frequent additional payments based on sales (see letters of 16 June 1857 and 3 April 1858 on the payment for Little Dorrit). In the literature, one even finds total sums paid to authors as high as $\mathrm{M} 50,000$ 7 This is probably the case for both $A$ Christmas Carol and Martin Chuzzlewit, and perhaps also for at least some of the volumes of Dombey and Son, David Copperfield Bleak House, Little Dorrit, Our Mutual Friend and Edwin Drood. See Pressler, p. 71; Todd/Bowden, pp. 27; 40; 64; 75; 95; 156; 209; 775; also PE III, p. 579, fn.

${ }^{8}$ However, this novel was published in four volumes, which brings down the payment per volume to well below $£ 40$. This is in accordance with the amount mentioned by Todd / Bowden (pp. 120-121) in their detailed discussion of the various sums paid to different authors (depending on the respective reputation and selling power and ranging from $£ 25$ to $£ 100$ per volume). Nowell-Smith op.cit. (pp. $432 \mathrm{ff}$.) puts the range at $£ 15$ to (100 pointing out that it became customary for Tauchnitz to start with a payment of $c$. 100 , poin a co for is also backed up by the only three existing contracts in the Staatsarchiv Leipzig: two with John Galsworthy for The Man of Property $(1909, £ 25)$ and Plays vol. 1 (1912, £20), and one with Edgar Wallace for The Ringer $(1928$, \&50).
(Macaulay, overall sum), or M8,000 for a single book (Bulwer Lytton for Kenelm Chillingly) ${ }^{9}$ - but these are clearly exceptions and seem higher because of exchange rates (roughly: $\mathrm{\& 1}=\mathrm{M} 20$ ).

The relationship between Tauchnitz and Dickens was more than a mere professional association, however. 'They met at least twice, once in London in 1855 and once in Paris in 1856, as far as I could ascertain, and there are several passages in the letters in which Dickens regrets having missed Tauchnitz when he was in London. Increasingly, Dickens is asking Tauchnitz about things outside their purely professional relationship, such as translations of his works into French and how much one should charge for that (letter of 12 December 1855, PE VII, p. 764), or even forwarding a query by his friend Wilkie Collins about a similar matter to Tauchnitz (letter of 6 December 1856). As it is pointed out in the entry on "publishing, printing, bookselling" in Paul Schlicke's Companion to Dickens, ${ }^{10}$ this is an exception to the rule of increasing professionalization rather than personalization in publishing in general and in Dickens's relations with his publishers in particular (which were often strained and repeatedly severed) - which emphasizes the unusual friendship between Dickens and Tauchnitz. As 'Tauchnitz wrote to Dickens's friend and biographer John Forster after Dickens's death: "Our long relations were not only never troubled by the least disagreement, but were the occasion of most hearty personal feelings, and I shall never lose the sense of his kind and friendly nature." (quoted in Todd / Bowden, p. 912) The clearest sign of Dickens's closeness to Tauchnitz was his decision to send his eldest son, Charles Dickens junior (better known as Charley) to Leipzig for almost two years in 1853-4. Several of the letters refer to this episode, which is hardly commented on in the biographies and writings about Dickens; in most accounts, there is at best a brief mention of a short stay of "some months". ${ }^{11}$ The reason for Charley's stay was that he wanted to go into business (or at any rate this was what Dickens apparently wanted him to do), and it was considered important to know German for this profession at the time. Only a few weeks after Dickens

9 See e.g. Böhnke, "Angelsächsisches in Sachsen"; Todd / Bowden, pp. 120-121

10 Oxford Reader's Companion to Dickens, ed. Paul Schlicke (Oxford: Oxford University Press, 1999), pp. 480ff.

${ }^{11}$ Michael Slater, Charles Dickens: A Life Defined by Writing (New Haven and London: Yale University Press, 2009), p. 365 (only a half-sentence); Claire Tomalin, Charles Dickens: A Life (London: Penguin, 2012), pp. 246-7; Robert Gottlieb, Great Expectations: The Sons and Danghters of Charles Dickens (New York: Farrar, Straus and Giroux, 2012), pp. 36-7; even PE VI, p. 833, fn (although the later volumes clearly show the length of the stay). The lack of detail on this episode in Gottlieb's recently published group biography of Dickens's children is the book has two whole chapters on name and gives no indication of the length of Charley's stay, let alone the impact it might have had on his development. 
first approached Tauchnitz about this at the end of 1852, Charley arrived in Leipzig in early March 1853, to stay there until December 1854 with one longer interruption over Christmas 1853 and January 1854. He stayed with a Professor Dr. O.C. Müller (though perhaps rather a school master) at Tauchaer Str. 6, and was taught German and various other mostly technical subjects by him and some other teachers, including Dr. Otto Fiebig of the Nikolaischule. ${ }^{12} \mathrm{He}$ was clearly not apprenticed to Tauchnitz in any way, as some texts suggest. This episode and the respective correspondence is certainly interesting in various ways, e.g. concerning Dickens's attitude towards his children, education, and Germany more generally, as I have suggested elsewhere, ${ }^{13}$ but for our present purposes it serves to illustrate the amicable relationship between the Dickens and Tauchnitz families, which continued until Dickens's death and beyond. ${ }^{14}$

\section{The Correspondence}

Given their long professional association and friendship, it is to be assumed that the correspondence between Dickens and Tauchnitz amounted to several hundred letters. Of these, the Pilgrim Edition of Dickens's letters only lists 29, spanning the period from 1843 to $1870 .{ }^{15}$ Among our 34 copies of letters by Dickens, there are 14 which are not contained in the PE, and another seven only in short extracts. This brings the number of known letters to 43 (we are only concerned here with letters by Dickens, of course, those by Tauchnitz being either lost or at least much more difficult to locate). Concerning the actual content of the letters, they are for the largest part receipts of sums paid by Tauchnitz for Dickens's works, and announcements of new work forthcoming. A few of them concern the question of translation (even though the

${ }^{12}$ Most of this information can be glimpsed from letters to various correspondents and the respective footnotes in PE VII, e.g. pp. 26; 37; 111-2; 134; 255; 287; 478.

${ }_{13}$ Dietmar Böhnke, "The Lost Leipzig Letters: Charles Dickens, Bernhard Tauchnitz and the German Connection", in: Dickens on the Move, ed. Stefan Welz (Frankfurt am Main: Peter Lang, forthcoming).

${ }_{14}$ Tauchnitz's own son seems to have stayed with Dickens on his travels to England, and Charley kept in contact with Tauchnitz, as our letters show. He did manage to learn German duing his con in Leipig but has some diffeus German duning his stay in Leipzig, but had sou dicte iciently to use it in his correspondence with Tauchnitz. He writes to him on 8 March 1880, for example: "You must excuse my writing in English. Alas! the German has almost entirely left me except for the simplest colloquial purposes."

${ }_{15}$ There are 31 entries for the correspondent Bernhard Tauchnitz, but one of them (August 1849) is only a mention of a letter rather than the letter itself, and another (18 April 1856) is really part of an earlier letter (8 April 1856), as we now know from the photocopies (see $\mathrm{fn}_{\mathrm{n}} 33$ ). All of the letters in PE are quoted after Der Verlag, with three exceptions: the Aunst 1849 mention (from a letter to FM. Fvans of 13 September 1849), he leter of 22 December 1860 (after the tacsinis in the 1937 Festschifi), an econd letter of 14 January 1861 (after the MS; this was a letter of introduction for an acquaintance of Dickens).
Tauchnitz Edition itself was in English, of course), and some others Charley's stay in Leipzig. Most of them are also very short - with one or two significant exceptions. While they are perhaps not groundbreaking, they illustrate Dickens's interest in the publication of his works abroad, and in questions of copyright and distribution, and of course his high regard for Tauchnitz. In addition, some interesting personal touches can be glimpsed from them, as for example in the change of Dickens's greetings from "Mrs Dickens and all my family beg to be kindly remembered to Madame Tauchnitz and all your family" in the letter of 16 June 1857 through "We are all well here, and unite in kindest regard and remembrance to Madame Tauchnitz and all your family" (3 April 1858) to "My daughters and their aunt beg to be kindly remembered to all your family; in which I cordially join." (31 March 1859); illustrating Dickens's marital crisis and eventual official separation from his wife, which happened at that time (Dickens's sister-in-law, Georgina Hogarth, chose to remain with him and the children after the separation) ${ }^{16}$

In the following transcriptions of the 14 new letters and seven completed ones, I have attempted to follow as closely as possible the style and format of the Pilgrim Edition, while my footnotes cannot possibly claim to rival the standard and expertise of the authoritative annotations by its editors. I would like to thank Mark Dickens, the current head of the Dickens family and President of the International Dickens Fellowship, for his permission to publish the transcriptions, my father Gunter Böhnke for doing the original transcriptions (and of course finding and copying the letters in the first place!), and Michael Slater for his helpful comments and corrections with some difficult words and passages.

\footnotetext{
${ }^{16}$ See for example Slater op. cit., pp. $447 \mathrm{ff}$.
} 
To BERNHARD TAUCHNITZ, 21 OCTOBER $1846^{17}$

Text from photocopy of MS Dr Dietmar Böhnke, Universität Leipzig

Rosemont, Lausanne I October Twenty First 1846.

Dear Sir.

I beg to acknowledge the receipt of your obliging letter of the $8^{\text {th }}$ Instant.

The seventeen pounds payable to me on account of the Pictures from Italy, you can either forward to Lausanne (where I shall remain until the tenth or twelfth of next month: when I go to Paris), or direct your London agent to pay in to my account with Messrs Coutts and Company, Bankers, Strand, London. The mode most convenient to you, will be the most agreeable to me.

In reference to the conditions on which I should be disposed to sanction your republication of my new book Dealings with the Firm of Dombey and Son, I am quite at a loss how to answer your question, as I really do not know what it would be fair and reasonable to require from you. But I have every reason to rely upon your honorable intentions; and if you will do me the favor to state your own proposal, I have little doubt that I shall be willing to assent to it.

I feel in the same position with reference to those older books of mine, Pickwick, Nickleby, Oliver, The Sketches, and the American Notes. Oblige me by communicating to me your own views on the subject of that ex post facto sanction which your conscientious and just feeling impels you to seek in reference to those works; and I shall be most happy to entertain [correction: *ar them in a favorable spirit.

Mons Le chevalier Bernh Tauchnitz.

I am Dear Sir | Very faithfully Yours Charles Dickens

17 This is the second extant letter from Dickens to Tauchnitz, after the initial one of 9 October 1843, clearly illustrating Dickens's high regard for Tauchnitz and his faith in his honesty and fairness. The third paragraph only (starting "In reference to...") is in PE IV, p. 642. Pictures from Italy appeared in 1846 as Vol. 103 in the Tauchnitz Edition. The compartively low payment is probably due to the shortness of the book and its

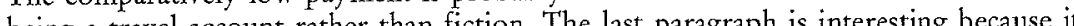

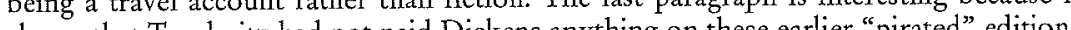
shows that Tauchnitz had not paid Dickens anything on these earlier "pirated" editions up to this point, even though the first "sanctioned" edition of a Dickens text, $A$ Christmas Carol (not in the main series, 1843), had been published by Tauchnitz almost three years earlier.
To BERNHARD TAUCHNITZ, 31 MARCH $1852^{18}$

Text from photocopy of MS Dr Dietmar Böhnke, Universität Leipzig London, Tavistock House I Thirty First March 1852

My Dear Sir

I beg to acknowledge the safe receipt of your draft for $£ 100$ sterling; namely $£ 50$ on account of Household Words, and $£ 50$ on account of Bleak House. I also return you, herewith, the counterpart of the Agreement, signed and sealed by myself and duly attested - not by the Consul, but, I believe, in an equally legal manner.

In reference to the Child's History of England, I may mention that I do not know whether you are aware that a large portion of it has already been collected and revised by myself, and published here as Volume I of the History, which it is purposed finally to complete in 3 Volumes of the same size. If you would like to have this book, I will take care to give it Messrs Williams \& Norgate $^{19}$ on their application. You are at perfect liberty to republish it on the continent in that form; but if you find you can make me any additional payment for doing so, I feel sure you will. The right of republication abroad, is becoming, through many circumstances, more valuable to me every day; and while I have the highest possible sense of your honorable and faithful conduct in all past

${ }^{18}$ This letter is unpublished. There are three more known letters between the one above and this one, of 11 April and 18 October 1847, and 23 November 1850 (PE V, pp. 56; 175-6; PE VI, p. 214). Of these, we have the last one only among our photocopies, but the text is almost complete in PE VI: the first sentence should be completed by "..., and also the unfortunate cause of your not visiting England." and the sum paid in

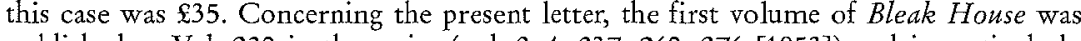
published as Vol. 230 in the series (vol. 2-4: 237, 260, 276 [1853]) and is particularly interesting for being the first book to be originally issued in parts by Tauchnitz, thereby imitating the typical way of publishing the novels in the UK. This does not seem to have been very successful, however, and was last attempted with Dickens's Edwin Drood in 1870. Of all those part issues, only a single copy has survived, according to Todd / Bowden (p. 75). In 1851, Tauchnitz began to reprint material from Dickens's weekly The Repinted from Household Words" (1856-9). Tauchnitz paid Dickens half-yearly sums of $£ 50$ for this, as the letters show. A Child's History of England was published in two volumes in 1853-4 (outside the main series). The last sentence of the letter is one of the few instances in which Dickens can be seen to put pressure on Tauchnitz to pay him more, thus slightly qualifying Tauchnitz's statement about there being "never [...] the least disagreement", quoted above.

${ }^{19}$ Sydney Williams of Williams \& Norgate was Tauchnitz's agent in London, and some of the correspondence between Dickens and Tauchnitz probably went through this firm. Indeed, of our letters is by Dickens to Sydney Willians (1 February 1846 unplished) abo unpublished), about some misunderstanding involving lauchniz 1 hate decided not to publish a transcription here because it is not to Tauchnitz himself and the matter it deals with remains obscure. 
transactions, I think it only right to [correction: unreadable] remark that I am in the frequent receipt of many offers for that privilege.

Receive the assurance of my sincere considerations I and Believe me My Dear Sir | Very faithfully Yours

The chevalier B. Taüchnitz ${ }^{20}$ Charles Dickens

\section{To BERNHARD TAUCHNITZ, 14 JANUARY $1853^{21}$}

Text from photocopy of MS Dr Dietmar Böhnke, Universität Leipzig

Tavistock House, London I Fourteenth January 1853 | Friday Evening My Dear Sir

I am very truly obliged to you for your kind letter, and for the comforting assurances you give me of your hospitable intentions towards my dear boy.

I shall certainly, on your advice, send him to Leipzig, if I can through your friendly means find a tutor and a friend for him there, with whom while he is improved he may be confidential and happy.

Excuse me if I trouble you by stating exactly what I wish.

I wish to place him in a house where he will not lose the classical and other knowledge he has gained, and where he can acquire German tboroughly. He was in France with me when he was young, and will very easily recover that language. While he is well looked after (as all boys require to be) I wish him to be not too obviously restrained, and to have the advantages of cheerful and good society. Such little comforts as a room to himself etc. (I mean a bedroom) he has been used to at Eton, where he was high in the school, and would of course require in this new position. I want him to have an interest in, and to acquire a knowledge of, the life around him, and to be treated like a gentleman though pampered in nothing. By punctuality in all things, great or small, I set great store.

If your kindness can recommend a good home for him of this kind, he will do honor to it hereafter, and I shall always consider myself under an obligation to such a tutor, and shall always be happy to bear my testimony to his

20 Dickens writes Tauchnitz's name with an "ü" several times, presumably because in German handwriting at the time " $\mathrm{u}$ " was commonly spelled " $\overline{\mathrm{u}}$ " to distinguish it from " $\mathrm{n}$ ".

${ }^{21}$ This is the longest among our letters and might be the longest Dickens ever wrote to Tauchnitz (four pages in the original). Only three sentences from the fourth paragrap ("While he...", "I want him..." and "By punctuality...") appear in PE VII, p. 11. However, there is a slightly shorter earlier letter, which is not among our copies (22 December 1852 , PE VI, Pp. 832-3) in which Dickens already explains the issue in almost identica 1852, terms, often ung the same we passage about Charley's character, which is rather more positive than some later statements Dickens made about him and his progress (e.g. letter to Angela Burdett Coutts, PE VII, pp. 244-6) services. Charley (for he bears my name) is an affectionate boy of an excellent disposition, quick, and of great natural abilities. He is lively, easily makes friends, and is pleasant-looking, and has pleasant and frank manners. I forget whether I told you his age -16

I should have him home for five or six weeks in the summer, and also at Christmas time. ${ }^{22}$

If, on enquiry, you can find a gentleman whom you rely on, for such a trust - and if you will further do me the great favor of obtaining me all necessary particulars respecting him and his terms and charges - I will speedily consider and decide. ${ }^{23}$ I think I mentioned to you in my former letter that Charley wishes to devote himself hereafter, to commercial pursuits.

The chevalier Bernhard Taüchnitz

I am always, my Dear Sir I Yours very faithfully

\section{To BERNHARD TAUCHNITZ, 15 FEBRUARY 1853}

Text from photocopy of MS Dr Dietmar Böhnke, Universität Leipzig

Tavistock House | Fifteenth February 1853

\section{My Dear Si}

Have you received a second letter I wrote you on the subject of my boy, a few weeks ago? If you have, and have not yet been able to find a German home for him, pray do not take the trouble to reply to this. But I write, in case my letter should by any chance have miscarried. It was rather a long and full one.

Ever faithfully Yours CHARLES DICKENS

${ }^{22}$ Charley did go home for Christmas, but probably not during the summers of 1853 and 1854, as far as we can judge from letters written by Dickens during that period.

${ }_{23}$ As I have pointed out, Tauchnitz did find the tutor and host for Charley in Prof. Müller (and Dr. Fiebig). Just how speedily Dickens decided is clear from the following letters. 
To BERNHARD TAUCHNITZ, 24 FEBRUARY $1853^{24}$

Text from photocopy of MS Dr Dietmar Böhnke, Universität Leipzig

Tavistock House. I Thursday Twenty Fourth February 1853. My Dear Sir.

I received your kind letter this morning. Charley and his attendant ${ }^{25}$ will leave London next Monday night, and go straight, by way of Calais, to Cologne. They will sleep at Cologne on Tuesday; and at Frankfort on Wednesday; and they will come on to Leipzig by the first convenient train on Thursday morning.

With many thanks and I much regard, my Dear Sir I Ever Faithfully Yours The chevalier Bernhard Taüchnitz ChARles Dickens

\section{To BERNHARD TAUCHNITZ, 2 APRIL 1853}

Text from photocopy of MS Dr Dietmar Böhnke, Universität Leipzig

Tavistock House, London. I Second April, 1853.

My Dear Sir.

I perfectly agree in all the suggestions you so kindly make in your letter, as to paying Dr Müller. ${ }^{26}$ If you will have the goodness to do as you propose, I shall be very much obliged to you.

Your interest in Charley and [correction: unreadable] the terms in which you mention him, fill his mother and myself with delight and gratitude. I assure you that he is truly sensible of the uncommon kindness he has received from your amiable family, and that in all his letters he refers to it, and to every member of your household, with the greatest affection and regard. His heart is quite won.

I do not think the third and last Volume of the Child's History will be ready for publication before October or November. We shall probably publish, so as to have the complete little work in good time for Christmas. But as it advances

24 This letter, as well as the ones preceding and following it, is unpublished. It is interesting to see how quickly such momentous decisions could be taken and the transport details organized even before the onset of modern-day globalization; as is clear from the preceding letter, Dickens could not be sure of Charley's going to Leipzig even a few days earlier.

25 This attendant seems to have been a staff member of Housebold Words named Johnson, and was praised by Dickens for his good services in this instance; see letter to W.H. Wills of 9 March 1853, and PE VII, p. 45, fn.

${ }^{26}$ Both Charley's education at Eton and his stay at Leipzig were paid for by Dickens's immensely rich friend and benefactor Angela Burdett Coutts. The overall cost of the latter amounted to c. $£ 300$ (see PE VII, pp. 244; 553). towards its completion, I will not fail to let you know exactly when you can have the concluding sheets. ${ }^{27}$

Mrs Dickens unites with me in cordial regards and thanks to yourself and family, and I am, my Dear Sir

The chevalier Bernhard Taüchnitz

Very Faithfully Yours CHARLES DICKENS

\section{To BERNHARD TAUCHNITZ, 23 JANUARY $1854^{28}$}

Text from photocopy of MS Dr Dietmar Böhnke, Universität Leipzig

My Dear Sir.

Tavistock House | Monday Night Twenty Third January | 1854.

I received by Charley when he came home for his Christmas holidays, a letter from Dr Müller of a nature very honorable to [correction: the Doctor's forethought and truthfulness, asking me to consider what I thought would be best for Charley's future disposal. I have written him by this same post, a letter in reply which I fear you will have the trouble of explaining to him, and which I therefore will not repeat here. But I think and hope you will agree with me that my reasons, therein briefly stated, for proposing to leave Charley at Leipzig only another six months, are sound and judicious.

I have looked over the memoranda of our accounts etc. which you had the kindness to forward to me while I was in Italy. Nothing can be clearer. If you will have the kindness to continue to make the needful payments to Dr Müller and to charge them against me, you will increase the very great obligation I already owe you, and which no arithmetical figures can ever express.

It was a matter of real regret to me that I was abroad when you were in London. For it would have given me true pleasure to have taken your hand and thanked you with all heartiness for your friendship. I hope to do so on the occasion of your next visit, and also that it will not be long before you return here.

Mrs Dickens and her sister unite with me in best regards to yourself and family. I am always my Dear Sir

The chevalier Bernhard Taüchnitz

Yours faithfully and obliged CHARLES DICKENS

27 This is a reference to the common practice by Tauchnitz to print his books from proof sheets, so as to publish as close to the original publication date as possible (or sometimes even shortly before that). This makes the Tauchnitz Edition a valuable resource for textual criticism, since it can contain variants on the UK or US first editions of the respective works.

${ }^{28}$ Only four sentences from this letter appear in PE VII, p. 256, starting with the third paragraph: "It was a matter [...] yourself and family." The original plan seems to have been to send Charley back to Leipzig only until the summer of 1854 . In the event, however, he stayed until the end of the year, as is clear from a letter to Arthur Ryland of 
To BERNHARD TAUCHNITZ, 27 MARCH $1854^{29}$

Text from photocopy of MS Dr Dietmar Böhnke, Universität Leipzig

Tavistock House I Twenty Seventh March 1854

My Dear Sir

Charles has written to me, to propose his going with some friends to Berlin at Easter time for a few days. Supposing the friends to be approved of in Leipzig, I am willing that he should make the journey. Will you kindly advance to him the necessary funds for that purpose? And when you happen to see Dr Müller, will you mention the expedition to him, and tell him with my compliments that I have not thought it worth while to trouble him with a French letter respecting it?

You have seen the [correction: announcements, no doubt, of my new story in Household Words. Would you wish to anticipate it or to have any particular and separate arrangement made respecting it? I shall be very happy to do any thing you may wish

My Dear Sir I Very faithfully Yours à Monsieur | Le chevalier Bernhard Taüchnitz CHARLES DickeNS

\section{To BERNHARD TAUCHNITZ, 8 OCTOBER $1855^{30}$}

Text from photocopy of MS Dr Dietmar Böhnke, Universität Leipzig

Folkestone, Kent. I Monday Eighth October 1855

My Dear Sir

Many thanks for your letter, which was perfectly plain, and written in far more scholarly English than your modesty can imagine.

I received your bill safely, for the balance of the half year's payment to Household Words.

You shall be supplied with the first Number of my new book in due time, and I will take care that the notice of the reservation of the translation right, appears on the cover.

It is a pleasure to me to renew our former terms and to have any dealings with one whom I so highly esteem.

6 December 1854, in which Dickens writes of Charley's imminent return and states that he "has lived two years in Germany" (PE I:VII, p. 478)

29 The second paragraph of this letter is in PE VII, p. 300. We know very little about Charley's time in Leipzig and who his friends were. The one we do know about was Francesco Berger, a musician (probably at the time a student at the famous Leipzis Conservatory founded by Mendelssohn), who was later to come to England and write the music for Dickens's productions of Wrikie Collins's plays The Lighthouse (1855) and (1854). Dickens refished as Vol. 307 in the Tauchnitz Edition (1854).
My family beg to be kindly remembered. Charley particularly wishes that I should present his regards to you. He is now in the House of Baring and Co., the great merchants, and is doing very well indeed.

My Dear Sir I always Very faithfully Yours

The chevalier Bernhard Tauchnitz.

CHARLES DICKENS

\section{To BERNHARD TAUCHNITZ, 5 NOVEMBER $1855^{31}$}

Text from photocopy of MS Dr Dietmar Böhnke, Universität Leipzis

Tavistock House, London. I Monday Fifth November 1855

My Dear Sir

Under the circumstances you state in your kind letter received this morning, I think I shall do well to accept the offer of M. Weber. Therefore let me hereby empower you to accept that gentleman's proposal, on my behalf. And pray let me thank you at the same time, cordially, for the trouble and interest you have taken in the business.

M. Weber's first No. shall be sent under cover to you. And you shall receive it three or four days before publication here.

The chevalier Bernhard Tauchnitz

My Dear Sir I Very faithfully Yours CHARLES DiCKENS

\section{To BERNHARD TAUCHNITZ, 8 DECEMBER $1855^{32}$}

Text from photocopy of MS Dr Dietmar Böhnke, Universität Leipzig

Paris, 49 Avenue des Champs Elysées I Saturday Eighth December 1855 My Dear Sir

I beg to acknowledge the safe receipt of your two bills amounting together to $£ 60$ sterling, and to return you the printed form of Agreement duly signed.

The chevalier Bernhard Taūchnitz Always My Dear Sir I Very faithfully Yours

\footnotetext{
${ }^{30}$ The first and fourth sentences of this letter appear in PE VII, p. 718. The new book is Little Dorrit, published as Vol, 350,360,380 and 390 in 1856-7. Dickens had already mentioned it in an earlier letter of 5 September 1855, which is among our copies but not reprod here because produced his bus not prosper in his business career in the long run, and later became sub-editor at Dickens's journal All the Year Round, the ownership of which he inherited at Dickens's death.

${ }^{31}$ This letter is unpublished. The person mentioned here is almost certainly Johann Jakob Weber (1803-1880), another Leipzig publisher, who printed several Dickens texts in translation, among them the very first Dickens translation anywhere, as far as I know: Die Pickwickier (Pickwick Club, 1837). His offer here was presumably for a translation of Little Dorrit by Moritz Busch, which appeared in 1856.

${ }^{32}$ Unpublished letter. The payments were probably for Little Dorrit, perhaps including the translation fee mentioned in the previous letter. There was another letter on 12 December 1855 , which is among our copies, asking about the acceptability of an offer for French translations of Dickens's works, the full text of which is in PE VII, p. 764.
} 
To BERNHARD TAUCHNITZ, 8 APRIL $1856^{33}$

Text from photocopy of MS Dr Dietmar Böhnke, Universität Leipzig

49 Champs Elysées, Paris | Tuesday Eighth April, 1856

My Dear Sir

I beg to acknowledge the safe receipt of your draft at 30 days after sight on Messrs Johnston and Co. of London, for $£ 50$ sterling, being the half-yearly payment due to Household Words.

I also duly notice your announcement that you desire to terminate the existing agreement at the expiration of a year from this time.

Having thus disposed of business, let me have the pleasure of adding that we all unite in kindest regards to Mrs Tauchnitz and your family, and that we shall all remember our meeting here with great pleasure, and shall always look forward to a renewal of that friendship - somewhere. Leipzig is at present among my castles in the air, mes châteaux en Espagne, but perhaps Germany and I may make a personal acquaintance yet.

The chevalier Bernhard Tauchnitz

My Dear Sir I Very faithfully Yours CHARLES DICKENS

\section{To BERNHARD TAUCHNITZ, 7 OCTOBER $1856^{34}$}

Text from photocopy of MS Dr Dietmar Böhnke, Universität Leipzig

Tavistock House, London / Tuesday Seventh October 1856

My Dear Sir

I have safely received your draft at eight days after date for $£ 50$ sterling. Allow me to acknowledge its receipt, with thanks.

On the other side, I send you what I think will be the plainest and most concise form of announcing what you wish.

I am happy to report that we are all quite well, and that Mrs Dickens and all my family unite in kindest regard to Madame Tauchnitz and all your family.

Believe me always I My Dear Sir I Very faithfully Yours CHARLES DiCKENS

33 The last paragraph of this letter is in PE VIII, but under two different dates: the first sentence correctly under 8 April (p. 85), the second wrongly under 18 April (p. 93) - the mistake is taken over from Der Verlag. Tauchnitz's reason for discontinuing the Housebold Words series in this form was probably that not all the material from the journal was well-suited to the Tauchnitz Edition, especially not the pieces on contemporary British political and social issues. $\mathrm{He}$ continued to print extracts from Housebold Words (mainly the fictional texts) until 1859, as pointed out above. Dickens never managed to come to Leipzig (he only passed through what is now Germany twice, in 1845 and 1846 ).

${ }_{34}$ The next five letters are all unpublished. The payment here is probably for the last Household Words volume.
Notice. ${ }^{35}$

The present series of republications from Household Words terminates with the present volume.

We intend, however, to republish, in occasional volumes, the works of Fiction written for Household Words. This new series will appear under the title of

\section{Novels and Tales}

reprinted from

Household Words

Conducted by Charles Dickens.

- and the first volume will [correction: soon be published

\section{To BERNHARD TAUCHNI'TZ, 6 DECEMBER $1856^{36}$}

Text from photocopy of MS Dr Dietmar Böhnke, Universität Leipzig

Tavistock House, London I Sixth December 1856

\section{My Dear Sir}

My friend Mr Wilkie Collins is anxious to have your opinion in reference to the letter on the other side. Nothing is said of paying anything for the right of translation; and he thinks, as a matter of principle, that he ought to have something, however little. Do you [correction: unreadable] think any thing is to be got? And if so, can you tell him the best way of getting it?

With kind regard from my family to yours | Believe me Ever | Faithfully Yours The chevalier Bernhard Tauchnitz

${ }^{35}$ This notice was printed in the last volume of Tauchnitz's Housebold Words series (No. 359 [1856], see Todd / Bowden, p. 96). The "Novels and Tales" series started with No. 376 in the same year. The word "Notice" and all the titles (including "Conducted by CD") are underlined with double strokes in the original.

36 The content of this letter is wrongly surmised as relating to an actual publication of a work by Collins in the Tauchnitz Edition in a footnote to a later letter by Dickens on the topic in PE VIII, p. 237. "The letter on the other side" is not contained among our photocopies. 
To BERNHARD TAUCHNITZ, 16 JUNE 1857

Text from photocopy of MS Dr Dietmar Böhnke, Universität Leipzig

OFFICE OF HOUSEHOLD WORDS I Tuesday Sixteenth June 1857

\section{My Dear M. Taūchnitz}

I beg to acknowledge with thanks, the safe receipt of your cheque for $£ 60$ sterling, in completion of the payment for Little Dorrit. ${ }^{37}$

I am happy to accept your offer of $£ 60$ sterling per annum for the permission to publish at Leipzig such of the Novels and Tales that appear in Household Words, as you shall think proper to select for that purpose. ${ }^{38} \mathrm{I}$ understand, as you desire, that the general provisions of our former agreement will apply to this. There is no doubt that the number of Novels and Tales published in Household Words will be at least as great in the future as it has been in the past.

It caused me much disappointment to have missed seeing you when you were in London; I hope to be more fortunate next time.

Mrs Dickens and all my family beg to be kindly remembered to Madame Tauchnitz and all your family. Pray believe me

\section{To BERNHARD TAUCHNITZ, 3 APRIL 1858}

Text from photocopy of MS Dr Dietmar Böhnke, Universität Leipzig

Tavistock House, I Tavistock Square, London. W.C. I Saturday Third April, 1858

My Dear Sir

I have safely received this morning, your bill at 8 days after sight for $£ 50-$ in payment of $£ 30$ for reprinting Novels and Tales from Household Words, and a further sum of $£ 20$ for Little Dorrit. I thank you very cordially and am much obliged to you.

We are all well here, and unite in kindest regard and remembrance to Madame Tauchnitz and all your family.

My Dear Sir I always very faithfully Yours CHARLES DICKENS

${ }^{37}$ See next letter for additional payment of $£ 20$, clearly showing that Tauchnitz paid his authors more than he needed to, if the sales were high.

${ }_{38}$ With this new agreement, Tauchnitz thus saved $£ 40$ per year as compared with the original Housebold Words agreement.
To BERNHARD TAUCHNITZ, $31 \mathrm{MARCH} 1859^{39}$

Text from photocopy of MS Dr Dietmar Böhnke, Universität Leipzig

OFFICE OF ALL THE YEAR ROUND I Thursday Thirty First March 1859

My Dear Mr Taüchnitz

I enclose you the advertisement of my new weekly publication, from which you will learn when it begins, and also that it will contain, from week to week, a new Story by me. That story will extend over about 8 months.

Will you let me know, at your convenience, what arrangement you may desire to make with me in reference to this new undertaking?

My daughters and their aunt beg to be kindly remembered to all your family; in which I cordially join.

Believe me always | Very faithfully Yours CHARLES DICKENS

\section{To BARON BERNHARD TAUCHNIT'Z, 17 OCTOBER $1860^{40}$}

Text from photocopy of MS Dr Dietmar Böhnke, Universität Leipzig

Gad's Hill Place, I Higham by Rochester, Kent. I Wednesday Seventeenth

My Dear Mr Tauchnitz

October 1860

I am very glad to receive your letter this morning, as I was just going to write to you.

The Uncommercial Traveller is finished for the present, but I may very probably write another series under the same title, bye and bye. I bring it to a close now, because I am about to produce in "All the Year Round", a new serial story of my own writing, which will be continued every week for Nine Months. It will be rather longer than "A Tale of Two Cities". Its title will be: "Great Expectations."

39 The new weekly publication is All the Year Round, which Dickens was about to start at this time because of his quarrels with the printers of Housebold Words, Bradbury and Evas when they refused to print he offician his wife Catherine in their other publications. Note the reference to his sister-in-law Georgina Hogarth in this letter, rather than "Mrs Dickens". Attached to this letter was the printed announcement of All the Year Round and an extract from "Rolls Court" for $26^{\text {th }}$ March (one printed page) on the legal conflict about the discontinuance of House bold Words between Bradbury and Evans on the one hand and Dickens and Wills (subeditor at Housebold Words) on the other. The new story is A Tale of Two Cities, which appeared as Vols. 479 and 480 in the Tauchnitz Edition (1859).

40 The second paragraph and part of the fifth („Having a pretty house $[\ldots]$ much attached") are in PE IX, p. 340, but without the precise date (as "mid-November 1860") Between the preceding letter and this one, there are four more (all among our copies), which are contained in PE IX more or less in full and therefore not reproduced here: the 
I shall be happy to concede to you, as usual, the right of republishing "Great Expectations", and will take care that you have the last sheets in due time. I am also happy to reply to your question concerning "The Uncommercial Traveller", that it is at your service, on any terms you think right.

I have omitted to mention that the first No. of "Great Expectations" will be published on the $1^{\text {st }}$ of December.

Having a pretty house and grounds here, to which I am much attached, I have sold my home in London. But on my daughter's account, I purpose always having a house in London in what we call "The Season" - that is to say from [correction: February to June. When you next come over to England, I hope you will ensure me the opportunity of seeing you. Even this place is within an hour and a half's railway ride of "All the Year Round" office.

Charles is now in India, and has been in China and Japan. He will probably return home, early in next year. My daughter ( $\mathrm{I}$ use the singular number, now my second daughter is married), begs me to say that it would give her the greatest pleasure to receive Mrs Tauchnitz and any of your family. She and her aunt desire their kindest regard.

Believe me My Dear Mr Tauchnitz I always Faithfully Yours Charles Dickens

\section{To BARON BERNHARD TAUCHNITZ, 7 NOVEMBER $1860^{41}$}

Text from photocopy of MS Dr Dietmar Böhnke, Universität Leipzig

OFFICE OF ALL THE YEAR ROUND I Wednesday Seventh November 1860

\section{My Dear Mr Tauchnitz}

I have been travelling and have only just received your letter, or I would have answered it sooner.

dates are 7 April 1859 (p. 48; insert the sum of $£ 30$ in the first sentence, and before the last sentence: "Perhaps you may not consider it too much, to pay for this story, half of what you paid for Little Dorrit."), 18 April 1859 (p. 51; twice insert the sum of £35) 10 May 1859 (p. 63: insert the sum of $f 45$ ), and 2 December 1859 (p. 174; insert the sum

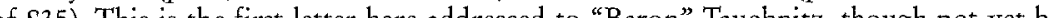
of 235 ). This is the first letter here addressed to "Baron" Tauchnitz, though not yet by ( to be sent from Gad's Hill Place in Rochester, Dickens's new home. The "Uncommercia Traveller" was published together with "Hunted Down" as Vol. 536 in 1860. Dickens did write a second series in 1868-9, but I have no proof that Tauchnitz published it. Great Expectations was published as Vols. 547 and 548 in 1861. The daughter that stayed with Dickens was Mamie; Katey married Wilkie Collins's brother, Charlie, in 1860.

${ }^{41}$ This letter is unpublished, and so are the next two. Between these, there are altogether eleven more letters, of which six are among our copies: these are nearly

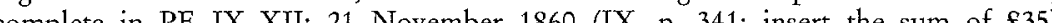
c 22 February 1864 (X, p. 360; containing the unusually high sum of $£ 150$ ), 17 June 1867
No. 77 contains the conclusion of the present series of the Uncommercial Traveller.

Believe me always | Faithfully Yours CHARLES DICKENS

To BARON BERNHARD TAUCHNITZ, 8 NOVEMBER $1865^{42}$

Text from photocopy of MS Dr Dietmar Böhnke, Universität Leipzig

Gad's Hill Place, I Higham by Rochester, Kent. I Wednesday Eighth November 1865 My Dear Baron

I beg to acknowledge the safe receipt this day, of your draft in payment of the second moiety of the sum agreed between us for "Our Mutual Friend". With thanks, and all good wishes for yourself and family. Believe me

The Baron Tauchnitz as always I Very faithfully Yours Charles Dickens

\section{To BARON BERNHARD TAUCHNIT"Z, 31 MARCH $1870^{43}$}

Text from photocopy of MS Dr Dietmar Böhnke, Universität Leipzig

OFFICE OF ALL THE YEAR ROUND I Thursday Thirty First March 1870 My Dear Baron

I beg to acknowledge the safe receipt of your draft for $£ 75$, and also to return you the agreement between us, duly signed by myself.

The Baron Tauchnitz

Believe me always | Faithfully Your Friend

CHARLES DICKENS

(XI, p. 381; insert the sum of $£ 35$, followed by "and to thank you for your letter."), 17 March 1870 (XII, p. 492), and 24 March 1870 (XII, p. 498; it is really the full text, so delete “..."). The letters in PE only are of 22 December 1860 (IX, p. 351, after the facsimile in the 1937 Festschrift), 14 January 1861 (two letters, IX, pp. 368-9), 15 July 1861(IX, p. 439), and 10 May 1862 (X, p. 82).

${ }^{42}$ The sum paid should have been $£ 75$. The sum for the first instalment (also £75) is correctly surmised in the PE note to the letter of 22 February 1864, but this second instalment is not mentioned.

${ }^{43}$ The payment and the agreement are for The Mystery of Edwin Drood, Dickens's last and unfinished novel, the fragment of which was published by Tauchnitz as Vols. 1100 and 1116 of the Tauchnitz Edition in 1870. These were the last 'real' Dickens volumes in the series, followed only by his letters (Vols. 1868-70 and 2032, [1880/2]), and a collection of his early writings (The Mudfog Papers, Vol. 1935, [1880]). 